\title{
Artificial Intelligence-Based Aircraft Accident Threat Parrying Method
}

\author{
A. Kulik ${ }^{1}{ }^{*}$ \\ ${ }^{1}$ Bauman Moscow State Technical University, \\ Moscow, 105005, Russian Federation \\ *E-mail: kulikalekse@yandex.ru
}

\section{Информация о статье}

Received 28th October 2021

Revised 16th November 2021

Accepted 18th November 2021

For citation: Kulik A. Artificial Intelligence-Based Aircraft Accident Threat Parrying Method. Proc. of Telecom. Universities. 2021;7(4):110-117. (in Russ.) DOI:10.31854/1813-324X-2021-7-4-110-117

\begin{abstract}
An anti-aircraft accident method is proposed, implemented in the decision support module, which is the main element of the flight safety control system and is a dynamic expert system. On the basis of the proposed method, recommendations are formed to the threat countering crew accidents using the information about its psychophysical state, the technical state an aircraft, external influencing factors, as well as a forecast of changes in flight conditions. The advantage of the proposed method is the ability to identify the immediate threat of an accident, as well as the development of management decisions to reduce the impact of the cause of the accident on flight safety. The peculiarity of the method of parrying the threat of an aircraft accident is the classification of management decisions depending on the flight conditions of the aircraft, which will reduce the computational costs for generating a threat parrying signal. Numerical modeling of the work using the assessment of a set of decision support rules made it possible to confirm its performance. The results can be used in systems development for safety an aircraft's flight, the mathematical support of decision support systems.
\end{abstract}

Keywords: flight safety, expert system, decision support.

\section{Introduction}

In recent years, the active development of aviation technology has largely helped to raise the level of flight safety of aircraft of various types. One of the methods to ensure flight safety is the use of various decision support systems as part of the onboard complex of the vessel. For example, an intelligent decision support system that is element of a complex control system and used for intelligent recommendation to aircraft crew actions in the form of expert solutions [1].

The operation of the system is based on obtaining and evaluating information about the hardware and software condition of the onboard equipment and the flight conditions of the aircraft. Another example of aircraft flight safety devices are systems that averting the threat of an aircraft incident on the runway [2-3] Such systems transmit information to the aircraft crew in the form of sound and light alerts, characterizing the excess of the permissible speed and the wrong flight route during the landing approach.

There is also the "Method for supporting an aircraft operator in hazardous situations" [4], during the implementation of which knowledge baselines are formed regarding the flight modes of aircraft and could be the threats of aircraft incidents. Later, on the basis of the expert system, the serviceability of the airborne equipment complex (AEC) of the aircraft, the effectiveness of the pilot's actions and the type of signaling is defined.

Based on the results of the operation of the expert system, information is generated about the failure of the AEC elements, the deterioration of flight conditions, the degree of an aviation accident. Based on the information received and analyzed, the system issues instructions to the pilot to resist an aviation catastrophe. In the absence of a positive reaction from the pilot parry the threat, the aircraft is controlled by an automatic control system.

Also, the operation of the system includes the operator's actions by the ground control point, which, with the help of a password, can allow the crew to control the aircraft without restrictions from the side of the aircraft's automatic flight control system (AFCS). With the planned elimination of the danger of an aircraft accident is required without limiting the actions of the raft, then the operator of the ground control post enters the corresponding password, which is transmitted to the expert system of the aircraft. In 
case of operational parrying of the aircraft accident and violation aircraft flight operation mode, its control is transmitted to the AFCS of the aircraft.

The disadvantage of such systems is the lack of an integrated approach to evaluation of aircraft flight safety on the basis of the aggregate influence of external and internal influence factors, including considering the prognosis of changes in them. The use of emergency forecasting devices at an early stage allows the team to warn the accident in advance and subsequently fend it off. Therefore, a promising option for enhancing aircraft flight safety is its flight safety control system. The structural diagram of the aircraft safety control system is shown in Figure 1.

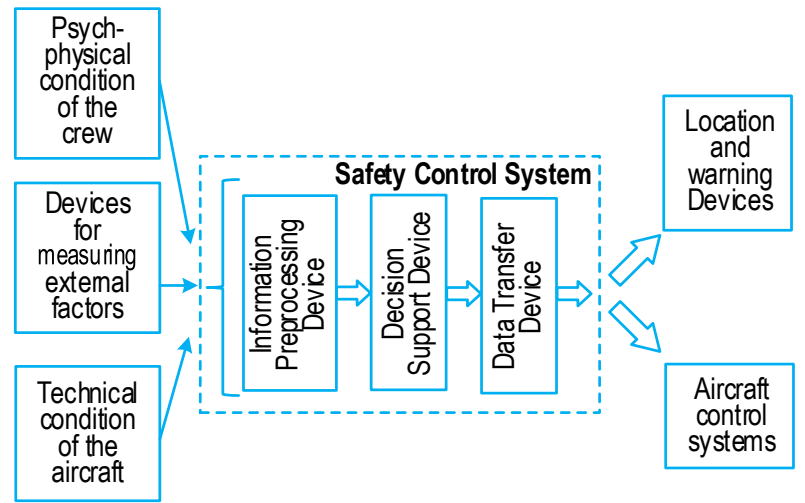

Fig 1. Structural Diagram of the Aircraft Safety Control System

The main elements of the proposed aircraft flight safety control system are information preprocessing device, decision support device and data transfer device. The preliminary data processing consists in the formation of electrical signals characterizing the excess current values of aircraft flight safety coefficients based on data obtained from the information measuring systems of the onboard equipment complex. Later, on the basis of information about changes in the flight conditions of the aircraft, the decision support device forms a conclusion characterizing the degree of danger of the flight event and methods for its elimination.

In the meantime, each group contains a list of input variables that measure the values of flight safety factors and their effect on flight conditions. A feature of these factors is their weak formalization. Therefore, the input variables of the flight safety control system are transformed into the form of linguistic variables. Each linguistic variable is defined on a set of fuzzy values that relate to a certain space-time interval. The representation of the input data of the decision support unit in the form of linguistic variables allows their processing by the fuzzy logic device, which is widely used in decision support devices and aircraft control systems [5-12].

\section{Formulation of the problem}

The purpose of this work is to design the method for decision support (DS) for the crew, which allows the formation of recommendations to the pilot and signals to the aircraft control system to counter the accident threat, based on the current and predicted flight conditions of the aircraft.

To achieve this goal, it is necessary to carry out the following main stages: formalization of the input variables of the algorithm, formation of a set of decision support rules and modeling of an accident threat assessment.

\section{Formalization of Input Variables}

The proposed decision support device belongs to the class of dynamic expert systems, a feature of which is the formation of instructions for the operator to counter an accident, taking into account the change in the state of the input variables at a given time interval. The structure scheme of the decision support device (DSD) is shown in Figure 2 [13].

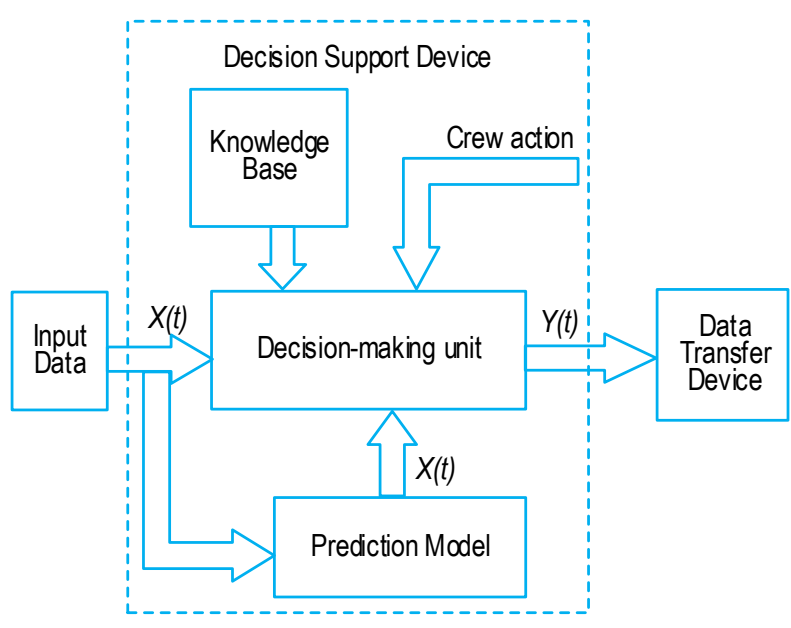

Fig. 2. Structure Scheme Decision Support Device

Here $X(t)$ - array of input data after preprocessing; $\tilde{X}(t)$ - the results of predicting the threat of an aviation accident; $Y(t)$ - output values from decision support units that describe the instructions given to the pilot to avert the risk of an emergency or to parry signals by onboard automated systems.

The input of the device receives variables that are associated with external and internal influences and affect the safe flight environment of the aircraft. Flight safety assessment is carried out on the basis of information on the technical state of the control object, psychophysical characteristics of the crew and flight weather conditions. Also, the inputs of the decision support unit are the values of the prognosis of changes in the controlled variables, the flight conditions of the aircraft and the current value of the accident risk. The output values of the device are instructions generated for the pilot to eliminate the risk of the catastrophic, as well as signals to counter it provided by onboard automation systems. A formalized representation of the input variables of the decision-making unit is presented in Table 1. 
TABLE 1. Input Variables of the Decision - Making Block

\begin{tabular}{|c|c|c|c|c|c|c|}
\hline № & Group & Variable & $\begin{array}{l}\text { Current Variable } \\
\text { Designation }\end{array}$ & $\begin{array}{c}\text { Forecast Variable } \\
\text { Designation }\end{array}$ & Variable Values & $\begin{array}{c}\text { Variable Value } \\
\text { Notation }\end{array}$ \\
\hline \multirow{4}{*}{1.} & \multirow{4}{*}{$\begin{array}{l}\text { The Psychophysical } \\
\text { State of the Pilot }\end{array}$} & Fatigue & $X_{11}$ & $\widetilde{X_{11}}$ & $\begin{array}{l}\text { Low } \\
\text { Average } \\
\text { High }\end{array}$ & $\begin{array}{l}F_{1} \\
F_{2} \\
F_{3}\end{array}$ \\
\hline & & Attention & $X_{12}$ & $\widetilde{X_{12}}$ & $\begin{array}{c}\text { High } \\
\text { Average } \\
\text { Low } \\
\text { Distracted } \\
\end{array}$ & $\begin{array}{l}K_{1} \\
K_{2} \\
K_{3} \\
K_{4} \\
\end{array}$ \\
\hline & & $\begin{array}{l}\text { Level of Training } \\
\text { (Competence) }\end{array}$ & $X_{13}$ & $\widetilde{X_{13}}$ & $\begin{array}{l}\text { High } \\
\text { Average } \\
\text { Low }\end{array}$ & $\begin{array}{l}F_{1} \\
F_{2} \\
F_{3}\end{array}$ \\
\hline & & Stress & $X_{14}$ & $\widetilde{X_{14}}$ & $\begin{array}{c}\text { No } \\
\text { Low } \\
\text { Average } \\
\text { High }\end{array}$ & $\begin{array}{l}K_{1} \\
K_{2} \\
K_{3} \\
K_{4} \\
\end{array}$ \\
\hline \multirow{4}{*}{2.} & \multirow{4}{*}{$\begin{array}{l}\text { Aircraft Technical } \\
\text { Condition }\end{array}$} & $\begin{array}{c}\text { Failure of } \\
\text { Functionally } \\
\text { Significant Elements }\end{array}$ & $X_{21}$ & $\widetilde{X_{21}}$ & $\begin{array}{c}\text { Minor } \\
\text { Emergency } \\
\text { Catastrophic }\end{array}$ & $\begin{array}{l}F_{1} \\
F_{2} \\
F_{3}\end{array}$ \\
\hline & & $\begin{array}{c}\text { Deformation of } \\
\text { Structural Members }\end{array}$ & $X_{22}$ & $\widetilde{X_{22}}$ & $\begin{array}{c}\text { Absent } \\
\text { Minor } \\
\text { Significant } \\
\text { Critical } \\
\end{array}$ & $\begin{array}{l}K_{1} \\
K_{2} \\
K_{3} \\
K_{4} \\
\end{array}$ \\
\hline & & $\begin{array}{c}\text { Aircraft } \\
\text { Controllability and } \\
\text { Stability } \\
\end{array}$ & $X_{23}$ & $\widetilde{X_{23}}$ & $\begin{array}{c}\text { High } \\
\text { Average } \\
\text { Low } \\
\end{array}$ & $\begin{array}{l}F_{1} \\
F_{2} \\
F_{3} \\
\end{array}$ \\
\hline & & $\begin{array}{c}\text { Error in the } \\
\text { Software of Aircraft } \\
\text { Control Systems }\end{array}$ & $X_{24}$ & $\widetilde{X_{24}}$ & $\begin{array}{c}\text { Absent } \\
\text { Minor } \\
\text { Significant } \\
\text { Critical } K_{4}\end{array}$ & $\begin{array}{l}K_{1} \\
K_{2} \\
K_{3} \\
K_{4}\end{array}$ \\
\hline \multirow{3}{*}{3.} & \multirow{3}{*}{$\begin{array}{l}\text { External Influencing } \\
\text { Factors }\end{array}$} & Headwind & $X_{31}$ & $\widetilde{X_{31}}$ & $\begin{array}{l}\text { Week } \\
\text { Average } \\
\text { Strong }\end{array}$ & $\begin{array}{l}F_{1} \\
F_{2} \\
F_{3}\end{array}$ \\
\hline & & Visibility & $X_{32}$ & $\widetilde{X_{32}}$ & $\begin{array}{c}\text { Good } \\
\text { Bad }\end{array}$ & $\begin{array}{l}K_{1} \\
K_{2} \\
\end{array}$ \\
\hline & & Side Wind & $X_{33}$ & $\widetilde{X_{33}}$ & $\begin{array}{l}\text { Week } \\
\text { Average } \\
\text { Strong } \\
\end{array}$ & $\begin{array}{l}F_{1} \\
F_{2} \\
F_{3} \\
\end{array}$ \\
\hline 4. & $\begin{array}{l}\text { Pre-Processing } \\
\text { Results }\end{array}$ & Flight Conditions & $Z$ & $\tilde{Z}$ & $\begin{array}{c}\text { Free } \\
\text { Hard } \\
\text { Emergency } \\
\text { Catastrophic } \\
\end{array}$ & $\begin{array}{l}K_{1} \\
K_{2} \\
K_{3} \\
K_{4} \\
\end{array}$ \\
\hline
\end{tabular}

The table shows the following variables:

a) Current Variables

$X_{1 i}$ - variables characterizing the psychophysical state of the pilot; $X_{2 i}$ - variables characterizing an aircraft technical condition; $X_{3 i}$ - variables characterizing an external influencing factors; $\mathrm{Z}$ - variables characterizeing the pre-processing results;

b) Forecast Variables $-\widetilde{X_{1 l}} ; \widetilde{X_{2 l}} ; \widetilde{X_{3 l}} ; \tilde{Z}$.

The table shows that each group is characterised by a set of input variables, on the basis of whom the state of flight protection factor and their affect on the risk of an emergency are evaluated. The peculiarity of this factors is their weak formalizability, therefore, the flight protection parameters of decision-making sustenancetors are represented in a linguistic form.

Together to evaluate the current flight environment of the airplane, it is expedient to use the feature of forecasting the threat of an aircraft incident, which provides for threefold stages: measurement of the values of influence factors at a given range of flight, receiving their relationships over the prognostic time, estimating the critical values of these parameters during the prognostication time with the determination of the moment of their emergence. As a consequence of the proposed approaches to evaluating and forecasting the risk of an aircraft accident, it is feasible to determine the reason affecting the crash during a given time period, as well as to develop guidelines for the team to counter an aircraft accident. The representation of the input data of the decision support unit in the form of linguistic variables allows their processing using the fuzzy logic apparatus, which is widely used in decision support devices and aircraft control systems [14-20].

\section{Formation of a Set of Rules for Decision Support}

Table 1 shows that the decision support rule has a rather complex structure, the implementation of which 
can lead to high computational costs. Therefore, it is advisable to structure the set of decision support rules into groups of aircraft flight conditions. It should be noted that the composition of the set of rules depends on the control object, its on-board equipment, functions performed and is determined in the process of developing the aircraft flight safety control system. Taking into account the division of the flight conditions of the vehicle into classes and applying the precedent matrix presented in [18], we obtain the following set of decision support rules.

1) Flight conditions are accident-free $Z=K_{1}$ :

RULE $<1>$ :

IF $X_{1 j}=\left\{F_{1}, K_{1}\right\} \& X_{2 j}=\left\{F_{1}, K_{1}\right\} \& X_{3 j}=$

$=\left\{F_{1}, K_{1}\right\}$ THEN $Y=\left\{G_{1}\right\}$,

here $G_{1}$ - threat of aviation accident is absent, parrying is not required.

2) Flight conditions are hard $Z=K_{2}$ :

RULE $<2.1>$ :

IF $X_{1 j}=\left\{F_{3}, K_{3}\right\} \& X_{2 j}=\left\{F_{1}, K_{1}\right\} \& X_{3 j}=$

$=\left\{F_{1}, K_{2}\right\}$ THEN $Y=\left\{G_{2}\right\}$,

RULE $<2.2>$ :

IF $X_{1 j}=\left\{F_{3}, K_{4}\right\} \& X_{2 j}=\left\{F_{1}, K_{1}\right\} \& X_{3 j}=$

$=\left\{F_{1}, K_{2}\right\}$ THEN $Y=\left\{G_{2}\right\}$,

RULE <2.3>:

IF $X_{1 j}=\left\{F_{2}, K_{2}\right\} \& X_{2 j}=\left\{F_{1}, K_{1}\right\} \& X_{3 j}=$

$=\left\{F_{1}, K_{2}\right\}$ THEN $Y=\left\{G_{2}\right\}$,

here $G_{2}$ - the threat of accident is counteracted by means of automation, the object's controllability is increased by signals from automatic control systems, stability and controllability are improved.

3) Flight conditions are emergency $Z=K_{3}$ :

RULE <3.1>:

IF $X_{1 j}=\left\{F_{1}, K_{3}\right\} \& X_{2 j}=\left\{F_{3}, K_{4}\right\} \& X_{3 j}=$

$=\left\{F_{2}, K_{1}\right\}$ THEN $Y=\left\{G_{3}\right\}$,

RULE $<3.2>$ :

IF $X_{1 j}=\left\{F_{1}, K_{1}\right\} \& X_{2 j}=\left\{F_{2}, K_{4}\right\} \& X_{3 j}=$

$=\left\{F_{3}, K_{1}\right\}$ THEN $Y=\left\{G_{3}\right\}$,

RULE <3.3>:

IF $X_{1 j}=\left\{F_{3}, K_{4}\right\} \& X_{2 j}=\left\{F_{2}, K_{3}\right\} \& X_{3 j}=$

$=\left\{F_{1}, K_{1}\right\}$ THEN $Y=\left\{G_{4}\right\}$,

RULE <3.4>:

IF $X_{1 j}=\left\{F_{2}, K_{2}\right\} \& X_{2 j}=\left\{F_{1}, K_{1}\right\} \& X_{3 j}=$

$=\left\{F_{3}, K_{2}\right\}$ THEN $Y=\left\{G_{4}\right\}$,

here $G_{3}$ - signaling to the crew about failures on board the control object, threat of accident with subsequent parrying by the pilot on the instruction are transmited of the speech translator; $G_{4}-\ldots$, a threat, followed by countermeasures by reconfiguring the control system of the object and landing on the nearest suitable site.

4) Flight conditions are catastrophic $Z=K_{4}$ :

RULE <4.1>:

IF $X_{1 j}=\left\{F_{2}, K_{3}\right\} \& X_{2 j}=\left\{F_{3}, K_{4}\right\} \& X_{3 j}=$

$=\left\{F_{2}, K_{1}\right\}$ THEN $Y=\left\{G_{5}\right\}$,

RULE $<4.2>$ :

IF $X_{1 j}=\left\{F_{3}, K_{4}\right\} \& X_{2 j}=\left\{F_{3}, K_{4}\right\} \& X_{3 j}=$ $=\left\{F_{3}, K_{4}\right\}$ THEN $Y=\left\{G_{5}\right\}$,

here $G_{5}$ - signaling to the crew about failures on board the control object, the threat of accident with the requirement to leave the control object.

From the presented set of rules it can be realized that in presence of failures of aircraft control systems and deterioration of weather conditions of the flight, an emergency situation may arise, which is parried by the pilot. If during the flight there was a deterioration in the psychophysical phase of the pilot and weather conditions with a good technical condition of the control object, then the emergency situation is countered by the aircraft safety control system. From the presented set of rules, it can be understood that in device, is similar to that presented by formulas (1-4) in terms of the flight condition. The formed set of rules for countering the risk of the crash is used in the algorithm of the crew decision support device, the action of which is signaling at generating and issuing instructions to the crew to prevent an accident with the identification of the source of its threat.

Using the proposed set of rules and the values of the input variables of the aircraft flight safety control system, the simulation of the risk of an aviation crash was performed out with the issuance of instruction to the crew on its parry. Modeling of flight conditions was carried out for difficult and trouble-free aircraft flight conditions, taking into account failures of onboard equipment and changes in flight weather conditions. The characteristics of the results of simulation the flight conditions of the aircraft are shown in Figure 3-4.

In the course of computational simulation of the flying environment of the aircraft the following stars were received:

- with linguistic variables being one, the significance of flight conditions is 1.0 , which equates to an accidentfree flying mode, hence there is no danger of an emergency, and countering the danger is not needed when the significance is equal in (Figure 3);

- with linguistic input variables corresponding to difficult flight conditions (a low level of aircraft controllability and an increase in crew fatigue from a monotonous load), an improvement in flight conditions by means of automation is required, which corresponds to (Figure 4). 


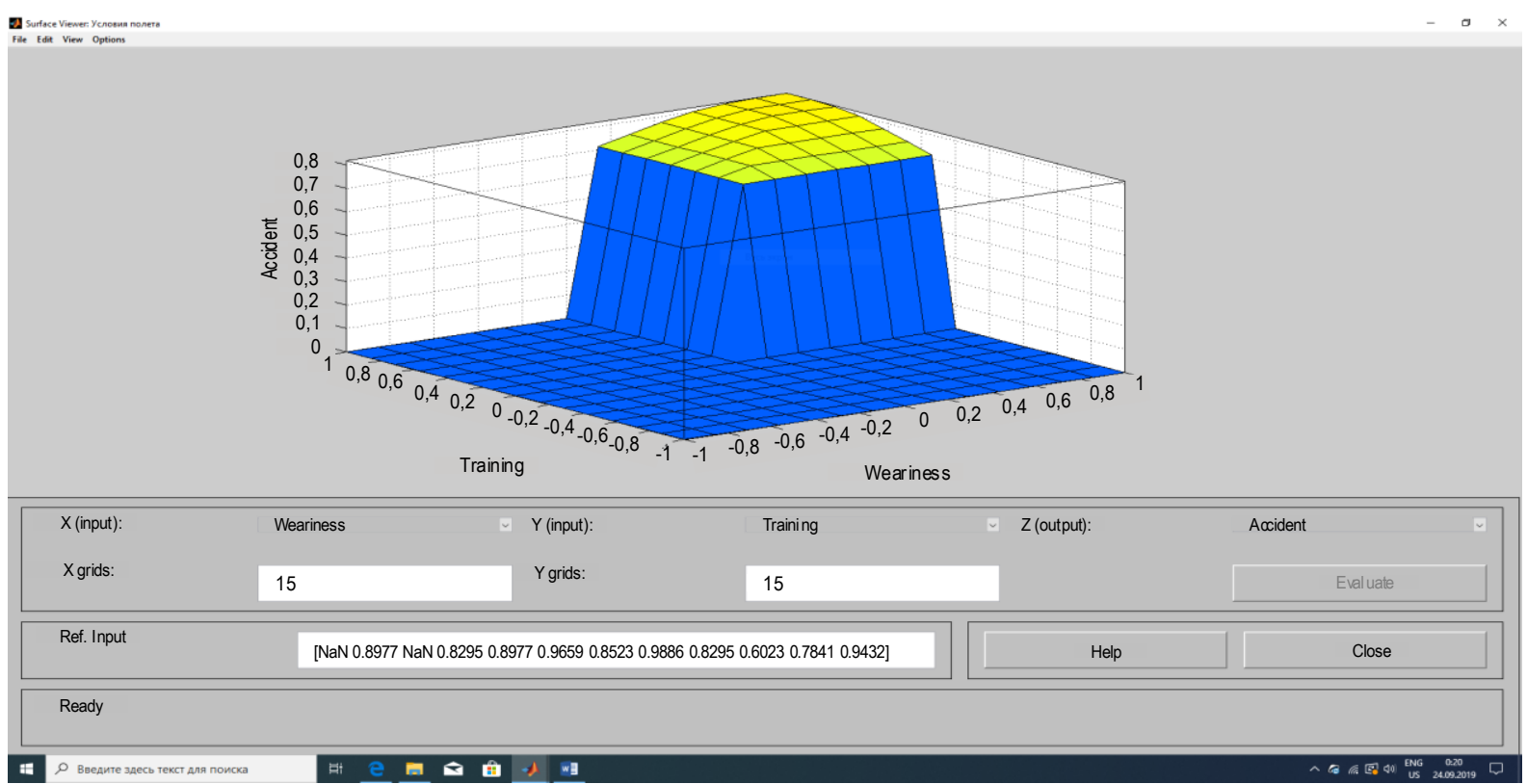

Fig. 3. Characteristics of the Results of Numerical Simulation of Aircraft Flight Conditions for an Accident-Free Situation

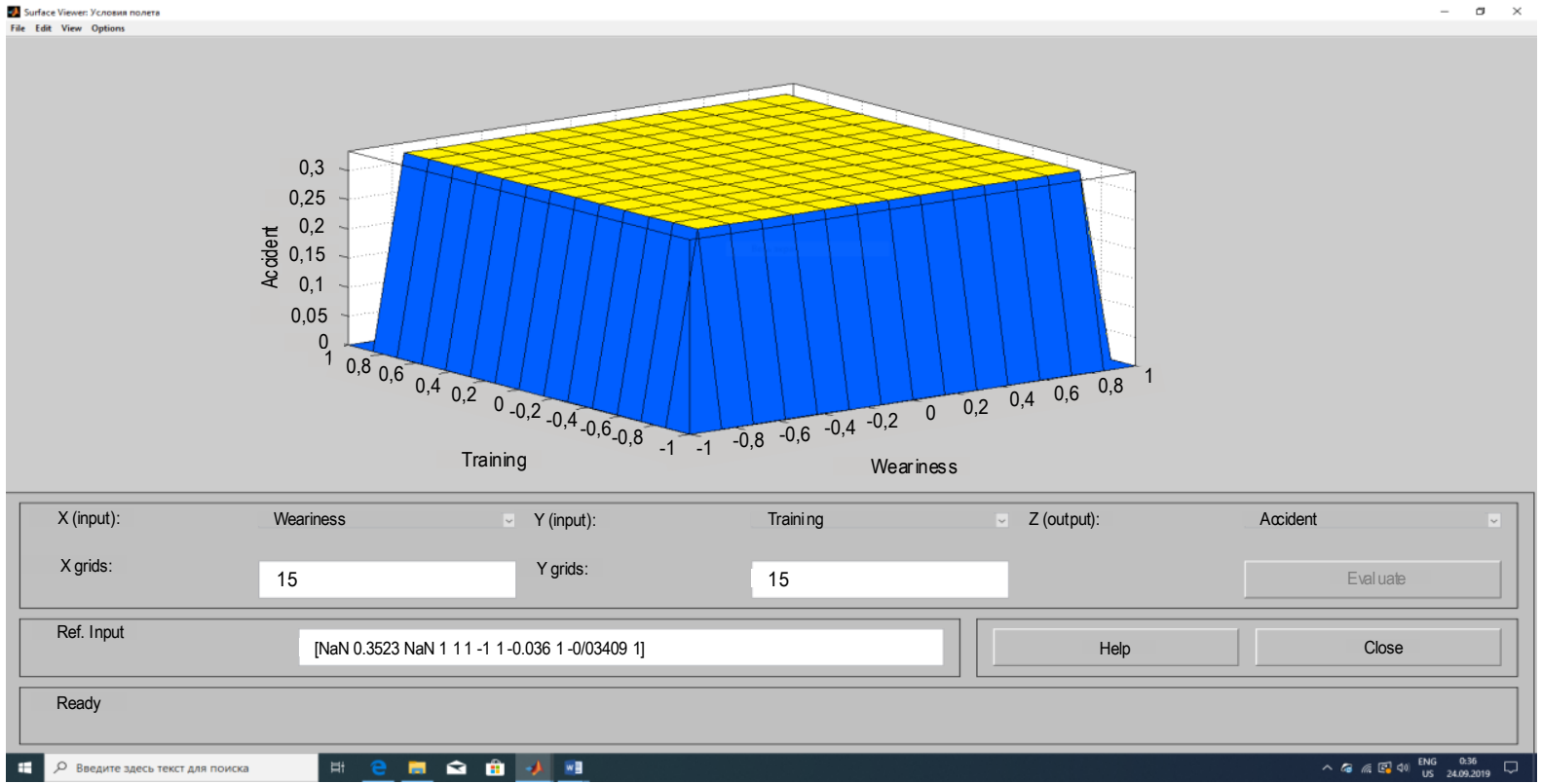

Fig. 4. Characteristics of the Results of Numerical Simulation of Aircraft Flight Conditions for a Complex Flight Condition

\author{
II. C:IUSERSIALEXEYAPPDATAILOCALITEMPIGOALSO00.EXE \\ Uslovia poleta \\ 1. Uslovia poleta bezavarinie \\ 2. Uslovia poleta sloznie \\ 3. Uslovia poleta avarinie \\ 4. Uslovia poleta katastroficheskie \\ 5.Uihod iz program. \\ $\Rightarrow 1$ \\ x11=f1-ustalost nizkay1. Yes \\ 1×12=k1-unimanie visokoe1. Yes \\ $1 \times 13=f 1-u r o v e n$ kompetencii uysokiy1. Yes \\ $1 \times 14=k 1-s t r e s s a$ net1. Yes \\ 1×21=f1-otkazou net1. Yes \\ $1 \times 22=$ k1-deformacii net1. Yes \\ $1 \times 23=f 1-u p r a v l i a e m o s t$ visokay1. Yes \\ 1×24=k1-neznacitelnay oshibka P.0.1. Yes \\ $1 \times 31=f 1-u s t r e c h n i y$ veter slabyi1. Yes \\ $1 \times 32=k 1$-vidimost horoshay1. Yes \\ 1x33=f1-bokovoy veter slabiy1. Yes \\ 1Ugroza AP otsutstuuet
}

a)

\author{
III C:IUSERS\ALEXEYAPPDATAILOCALITEMP\GOALSO00.EXE \\ Uslovia poleta \\ 1. Uslovia poleta bezauarinie \\ 2. Uslovia poleta sloznie \\ 3. Uslovia poleta auarinie \\ 4. Uslovia poleta katastroficheskie \\ 5.vihod iz program. \\ $\Rightarrow>2$ \\ $\times 11=f 3-u s t a l o s t$ visokay1. Yes \\ $1 \times 12=k 4-$ unimanie rassenoe 1 . Yes \\ $1 \times 13=f 3-u r o v e n$ kompetencii nizkiy1. Yes \\ $1 \times 14=k 4-s t r e s s a$ visokiy1. Yes \\ $1 \times 21=$ f1-otkazou net1. Yes \\ 1×22=k1-deformacii net1. Yes \\ $1 \times 23=$ f1-uprauliaemost visokay1. Yes \\ 1×24=k1-neznacitelnay oshibka P.0.1. Yes \\ $1 \times 31=$ f1-ustrechniy veter slabyi1. Yes \\ $1 \times 31=f 1$-ustrechniy veter slaby
$1 \times 32=$ k2-vidimost plohay1. Yes \\ $1 \times 32=k 2-v i d i m o s t$ plohay1. Yes
$1 \times 33=$ f1-bokovoy veter slabiy1. Yes \\ 1Ugroza AP. Pariruetsya automatikoi.
}

b)

Fig. 5. Characteristics of the Test Results of the Decision Support System: a) under Non-Emergency Flight Conditions of the Aircraft; b) under Difficult Aircraft Flight Conditions 
Based on the test methodology of the aircraft flight safety control system [21] and numerical simulation of flight conditions, the simulation of the formation of recommendations for countering the risk of the crash was carried out, the results of which are shown in Figure 5. From the information presented in Figure 5b, it follows that the decision support device is able to form instruction for the pilot on the actions of the risk of an accident through the means of on-board indication and signaling of the aircraft.

Based on the results of numerical simulation, it is feasible to define the conformity of a collection of rules of a decision support device to the index of completeness (IC) and absence of inconsistency (AI). So, when IC = 1, it corresponds to taking into account all possible states of input variables and changes in flight conditions. In turn, the validity of $\mathrm{AI} \leq 0,4$ characterizes the absence of inconsistency between the output variables of the set of decision support rules for the same values of the input variables.

Thus, the proposed method makes it feasible to formulate advice to the crew and management signaling to parry the risk of an accident, taking into consideration the foretold changes in extrinsic and internal factors influencing the flight condition of the airship.

\section{Conclusion}

In the course of the work, a method of fending off the danger of an aircraft accident was designed, consisting in the creation of command instructions for the crew and signals of on-board automation equipment to counter the danger of an aircraft accident using data on the current and predicted flying conditions of the aircraft.
At the same moment, the input variables of the decision support unit were analyzed, a set of rules for the knowledge base was formed, on that basis simulations be conducted to evaluate and counter the risk of an aviation accident. When compiling a set of rules, they were assessed for completeness and the absence of inconsistency, the indicators of which characterize the formed set of rules for the possibility of being applied as part of the aviation system. The decision support method in the event of an aviation accident threat makes it possible to determine the actions of the crew in the process of piloting the vessel, depending on the air situation and the values of the variables affecting the flight safety. Based on the method of decision-making support of the crew, an algorithm for parrying the threat of an accident is proposed, the action of which is aimed at generating a signal that initializes instructions to the crew on countering the accident. A distinctive feature of the algorithm is the formation of an aircraft control signal in automatic mode in the absence of a positive response from the pilot to counter the threat of an accident. In addition, when developing the algorithm, a classification of the set of rules was proposed depending on the flight conditions of the aircraft, which allows reducing the computational costs for generating a signal to parry the threat of an accident. Further work on the creation of aircraft flight safety control systems is aimed at its software and hardware implementation, followed by ground testing and testing as part of flying laboratories. At the same time, ground tests of the system presuppose its testing at the semi-natural simulation stand with simulated aircraft flight and changing the values of flight safety variables, which will ensure verification of its software.

\section{Reference}

1. Sapogov V.A., Anisimov K.S., Novozhilov A.V. Fail-Safe Computer System for Complex of Aircraft Flight Control Systems. Trudy MAI. 2011;45. (in Russ.)

2. Glubokaya M.G. The look of the onboard Decision Support System on Passenger Aircraft Takeoff Stage. Izvestiya RAN. Teoriya i sistemy upravleniya. 2009;3:105-121. (in Russ.)

3. Shevchenko A.M., Nachinkina G.N., Solonnikov Y.I. Modeling of the Pilot Information Support Tools at the Aircraft Takeoff Stage. Proceedings of the Moscow Institute of Electromechanics and Automation (MIEA). 2012;5:54-64. (in Russ.)

4. Sukholitko V.A. Method of Operator Support in Dangerous Situations. Patent RF, no. 2205442 C1 G05D, 02.10.2001. (in Russ.)

5. Wolf W. Cyber-physical system. Computer. 2009;42(3):88-89. DOI:10.1109/MC.2009.81

6. Rad C.R., Hancu O., Takacs I.A., Olteanu G. Smart Monitoring of Potato Crop: A Cyber-Physical System Architecture Model in the Field of Precision Agriculture. Agriculture and Agricultural Science Procedia. 2015;6:73-79. DOI:10.1016/j. aaspro.2015.08.041

7. Lee J., Bagheri B., Kao H.-A. A Cyber-Physical Systems architecture for Industry. 4.0-based manufacturing systems. Manufacturing Letters. 2015;3:18-23. DOI:10.1016/j.mfglet.2014.12.001

8. Kupriyanovsky V., Namiot D., Sinyakov S. A Cyber-physical system as the basis for the digital economy. The International Journal of org Open Information Technologies. 2016;4(2):18-25.

9. Kosko B. Fuzzy Systems as Universal Approximators. IEEE Transactions on Computers. 1994;43(11):1329-1333. DOI:10.1109/12.324566

10. Cordon O., Herrera F.A. General study on genetic fuzzy systems. In Genetic Algorithms in Engineering and Computer Science. John Wiley \& Sons; 1995. p.33-57.

11. Averchenkov V.I., Miroshnikov V.V., Podvesovskiy A.G., Korostelyov D.A. Fuzzu and Hierarchical Models for Decision Support in Software Systems Implementation. Proceedings of the 11th on Joint ConferenceKnowledge-Based Software Engineering, 17-20 September 2014, Volgograd, Russia. Communications in Computer and Information Science. Cham: Springer; 2014. vol.466. p.410-422. DOI:10.1007/978-3-319-11854-3_35

12. Denisov M., Kozin A., Kamaev V., Davydova S. Solution on Decision Support in Determining of Repair Action Using Fuzzy 
Logic and Agent System. Proceedings of the 11th on Joint ConferenceKnowledge-Based Software Engineering, 17-20 September 2014, Volgograd, Russia. Communications in Computer and Information Science. Cham: Springer; 2014. vol.466. p.533-541. DOI:10.1007/978-3-319-11854-3_46

13. Bolshakov A.A., Kulik A.A., Sergushov I.V., Skripal E.N. Design the Method for Aircraft Accident of Prediction. Mekhatronika, Avtomatizatsiya, Upravlenie. 2018;19(6):416-423. (in Russ.) DOI:10.17587/mau.19.416-423

14. Bolshakov A.A., Kulik A.A., Sergushov I.V., Skripal E.N. Development the Control System Algorithms Functioning of Flight Safety for the Aircraft of Helicopter Type. Izvestia of Samara Scientific Center of the Russian Academy of Sciences. 2016;18(1-2): 358-362. (in Russ.)

15. Fedunov B.E., Prokhorov M.D. Conclusion on the Precedent Knowledge Bases Airborne Intelligence Systems. Iskusstvennyj intellekt i prinjatie reshenij. 2010;3:63-72. (in Russ.)

16. Bahanov L.E., Demkin M.A., Fedunov B.E. Mathematical model of aircraft motion for knowledge bases of on-board operational advising expert systems. Izvestiya RAN. Teoriya i sistemy upravleniya. 2010;1:103-111. (in Russ.)

17. Nejmark M.S., Cesarskij L.G., Filimonyuk L.YU. Decision support model for aircraft entering the airport's area of responsibility. All-Russian Scientific-Technical Journal "Polyot" ("Flight"). 2013;3:31-37. (in Russ.)

18. Gavrilova T.A., Horoshevskiy V.F. Knowledge Bases of Intelligent Systems. St. Petersburg: Piter Publ.; 2000. 384 p. (in Russ.)

19. Kuklev E.A. Flight Safety Control of the Basis of Uncertain Risk Evaluation with Non-Routine Flight Conditions Involved. Civil Aviation High Technologies. 2016;226:199-205. (in Russ.)

20. Bolshakov A.A., Kulik A.A., Sergushov I.V., Skripal E.N. Aviation Accident Threat Intelligent Assessment Method. Vestnik komp'iuternykh i informatsionnykh tekhnologii (Herald of Computer and Information Technologies). 2018;5(167):3-9. (in Russ.) DOI:10.14489/vkit.2018.05.pp.003-009

21. Kulik A.A. Development of Methods for Test of Air Flight Safety System. Vestnik of Samara State Technical University. Technical Sciences Series. 2019;4(64):30-42. (in Russ.)

\title{
$* \quad * \quad *$ \\ Метод парирования угрозы авиационного происшествия на основе искусственного интеллекта
}

\author{
А.А. Кулик ${ }^{1} \mathbb{D}^{*}$ \\ ${ }^{1}$ Московский государственный технический университет имени Н.Э. Баумана, \\ Москва, 105005, Российская Федерация \\ Информация о статье \\ DOI:10.31854/1813-324X-2021-7-4-110-117 \\ Поступила в редакцию 28.10.2021 \\ Поступила после рецензирования 16.11.2021 \\ Принята к публикации 18.11.2021
}

Ссылка для цитирования: Кулик А.А. Метод парирования угрозы авиационного происшествия на основе искусственного интеллекта // Труды учебных заведений связи. 2021. T. 7. № 4. С. 110-117. DOI:10.31854/ 1813-324X2021-7-4-110-117

\begin{abstract}
Аннотация: Предлагается метод парирования угрозы авиационного происшествия, реализованный в модуле поддержки принятия решений, который является основным элементом системы управления безопасности полета летательного аппарата и представляет динамическую экспертную систему. На основе предложенного метода формируются рекомендации экипажу по парированию угрозы авиационного происшествия на основе информации о его психофизическом состоянии, техническом состоянии объекта управления, внешних воздействующих факторов, а также прогноза изменения условий полета. Преимущество предложенного метода является возможность идентификации непосредственной угрозы авиационного происшествия, а также выработка управленческих решений по уменьшению влияния причины происшествия на безопасность полета. Особенность метода парирования угрозы авиационного происшествия заключается в классификации управленческих решений в зависимости от условий полета воздушного судна, что позволит снизить вычислительные затраты на формирование сигнала парирования угрозы. Численное моделирование работы с использованием оценки набора правил поддержки принятия решений позволило подтвердить его работоспособность. Полученные результаты могут быть использоваться при разработке систем управления безопасностью полета летательных аппаратов, а именно математического обеспечения систем поддержки принятия решений.
\end{abstract}


Ключевые слова: безопасность полета, экспертная система, поддержка принятия решений.

\section{Список используемых источников}

1. Сапогов В.А., Анисимов К.С., Новожилов А.В. Отказобезопасная вычислительная система для комплексных систем управления полетом летательных аппаратов // Труды МАИ. 2010. № 45.

2. Глубокая М.Г. Облик бортовой системы поддержки принятия решений на этапе взлета пассажирского самолета // Известия РАН. Теория и системы управления. 2009. № 3. С. 105-121.

3. Шевченко А.М., Начинкина Г.Н., Солонников Ю.И. Моделирование средств информационной поддержки пилота на этапе взлета самолета // Труды Московского института электромеханики и автоматики (МИЭА). 2012. № 5. С. 54-64.

4. Сухолитко B.A. Способ поддержки оператора в опасных ситуациях. Патент на изобретение RUS 2205442 C1 G05D1/00 от 02.10.2001. Опубл. 27.05.2003.

5. Wolf W. Cyber-physical system // Computer. 2009. Vol. 42. Iss. 3. PP. 88-89. DOI:10.1109/MC.2009.81

6. Rad C.R., Hancu O., Takacs I.A., Olteanu G. Smart Monitoring of Potato Crop: A Cyber-Physical System Architecture Model in the Field of Precision Agriculture // Agriculture and Agricultural Science Procedia. 2015. Vol. 6. PP. 73-79. DOI:10.1016/j.aaspro.2015.08.041

7. Lee J., Bagheri B., Kao H.-A. A Cyber-Physical Systems architecture for Industry. 4.0-based manufacturing systems // Manufacturing Letters. 2015. Vol. 3. PP. 18-23. DOI:10.1016/j.mfglet.2014.12.001

8. Kupriyanovsky V., Namiot D., Sinyakov S. A Cyber-physical system as the basis for the digital economy // The International Journal of org Open Information Technologies. 2016. Vol. 4. № 2. PP. 18-25.

9. Kosko B. Fuzzy Systems as Universal Approximators // IEEE Transactions on Computers. 1994. Vol. 43. Iss. 11. PP. 1329-1333. DOI:10.1109/12.324566

10. Cordon O., Herrera F.A. General study on genetic fuzzy systems // In Genetic Algorithms in Engineering and Computer Science. John Wiley \& Sons. 1995. PP. 33-57.

11. Averchenkov V.I., Miroshnikov V.V., Podvesovskiy A.G., Korostelyov D.A. Fuzzu and Hierarchical Models for Decision Support in Software Systems Implementation // Proceedings of the 11th on Joint ConferenceKnowledge-Based Software Engineering (Volgograd, Russia, 17-20 September 2014). Communications in Computer and Information Science. Cham: Springer, 2014. Vol. 466. PP. 410-422. DOI:10.1007/978-3-319-11854-3_35

12. Denisov M., Kozin A., Kamaev V., Davydova S. Solution on Decision Support in Determining of Repair Action Using Fuzzy Logic and Agent System // Proceedings of the 11th on Joint ConferenceKnowledge-Based Software Engineering (Volgograd, Russia, 17-20 September 2014). Communications in Computer and Information Science. Cham: Springer, 2014. Vol. 466. PP. 533-541. DOI:10.1007/978-3-319-11854-3_46

13. Большаков А.А., Кулик А.А., Сергушов И.В., Скрипаль Е.Н. Метод прогнозирования авиационного происшествия летательного аппарата // Мехатроника, автоматизация, управление. 2018. Т. 19. № 6. С. 416-423. DOI:10.17587/mau. 19.416-423.

14. Большаков А.А., Кулик А.А., Сергушов И.В. Разработка алгоритмов функционирования системы управления безопасностью полета летательного аппарата вертолетного типа // Известия Самарского научного центра РАН. 2016. T. 18. № 1-2. С. 358-362.

15. Федунов Б.Е., Прохоров М.Д. Вывод по прецеденту в базах знаний бортовых интеллектуальных систем // Искусственный интеллект и принятие решений. 2010. № 3. С. 63-72.

16. Баханов Л.Е., Демкин М.А., Федунов Б.Е. Математическая модель движения самолета для баз знаний бортовых оперативно советующих экспертных систем // Известия РАН. Теория и системы управления. 2010. № 1. С. $103-111$.

17. Неймарк М.С., Цесарский Л.Г., Филимонюк Л.Ю. Модель поддержки принятия решений при входе воздушных судов в зону ответственности аэропорта // Полет. Общероссийский научно-технический журнал. 2013. № 3. С. 31-37.

18. Гаврилова Т.А., Хорошевский В.Ф. Базы знаний интеллектуальных систем. СПб: Питер, 2000. 384 с.

19. Куклев Е.А. Управление безопасностью полетов воздушных судов на основе нечетких оценок рисков возникновения нештатных условий полетов // Научный вестник МГТУ ГА. 2016. № 226. С. 199-205.

20. Большаков А.А., Кулик А.А., Сергушов И.В., Скрипаль Е.Н. Интеллектуальный метод оценки угрозы авиационного происшествия // Вестник компьютерных и информационных технологий. 2018. № 5(167). C. 3-9. DOI:10.14489/vkit.2018.05. pp.003-009

21. Кулик А.А. Разработка методики испытания системы управления безопасностью полета воздушного судна // Вестник Самарского государственного технического университета. Серия: Технические науки. 2019. № 4(64). С. 30-42.

\section{Сведения об авторе:}

КУЛИк Алексей Анатольевич кандидат технических наук, доцент, доцент кафедры Системы автоматического управления Московского государственного технического университета имени Н.Э. Баумана, kulikalekse@yandex.ru

(D) https://orcid.org/0000-0002-4099-1641 